\title{
KEBERADAAN BAKTERI Escherichia coli PADA AIR KOLAM RENANG UMUM
}

Indah Wahyuningtias, Bambang Sunarko, Iva Rustanti EW*

Jurusan Kesehatan Lingkungan, Poltekkes Kemenkes Surabaya

*Email korespondensi: ivarust.eri@gmail.com

\begin{abstract}
One indicator of swimming pool water pollution is the presence of Escherichia coli bacteria. Factors can caused the presence of Escherichia coli in pool water are the levels of residual chlorine, the visitors who dispose of metabolic waste (sweat, urine) in pool water and disinfection of pool that were not done properly. This study analyzes the quality of swimming pool water seen from the presence of Escherichia coli in public pool water.

This study was an observational analytic that use a cross sectional research design. The sample used were public swimming pool located in the Sukodono Health Center working area with total of pools were 10, and with Fisher's exact test.

The results showed that main factor affecting the presence of Escherichia coli in pool water was residual chlorine content with a p-value of 0.019 which means that there was a difference number of Escherichia coli in swimming pools containing residual chlorine and in pool water that didn't contain residual chlorine.

This study concluded that there were differences in the number of Escherichia coli bacteria in pool water containing residual chlorine and in pool water that did not contain residual chlorine. To keep the remaining chlorine in pool water in accordance with Permenkes No. 32 of 2017, pool managers should routinely check the remaining chlorine and do chlorination regularly.
\end{abstract}

Keywords: Escherichia coli, residual chlor, swimming pool

\section{PENDAHULUAN}

Salah satu tempat - tempat umum yang sering dikujungi sekaligus dijadikan sebagai obyek wisata adalah kolam renang. Kolam renang adalah tempat dan fasilitas umum berupa konstuksi kolam berisi air yang telah diolah yang dilengkapi dengan fasilitas kenyamanan dan keamanan baik yang terletak di dalam maupun diluar bangunan yang digunakan untuk berenang, rekreasi, atau olahraga air lainnya (Permenkes No 32 Tahun 2017). Keberadaan kolam renang di lingkungan masyarakat memiliki potensi sebagai tempat yang dapat menularkan penyakit, sehingga perlu diadakannya pengawasan untuk melindungi kesehatan masyarakat dari kemungkinan penularan penyakit dan gangguan kesehatan lainnya.

Penyakit akibat aktivitas berenang dikenal dengan sebutan recreationalwater illness (RWIs). RWIs disebabkan oleh kuman yang bertransmisi dengan cara menelan, bernapas dalam aerosol, atau memiliki kontak dengan air yang terkontaminasi di kolam renang, kolam air panas, taman air, area bermain air, air mancur interaktif, danau, sungai, atau laut. RWIs juga dapat disebabkan oleh bahan kimia dalam air atau bahan kimia yang menguap dari air dan dapat menyebabkan masalah kualitas udara dalam ruangan. RWIs meliputi berbagai macam infeksi, seperti pencernaan, kulit, telinga, pernapasan, mata, neurologis, dan infeksi luka terutama diare. Penyakit diare diakibatkan oleh kuman seperti Cryptosporidium, Giardia, Shigella, Norovirus dan E. coli O157:H7. (CDC, 2018).

Berdasarkan Peraturan Departemen Kesehatan RI Nomor 32 Tahun 2017, salah satu indikator parameter biologi untuk kualitas air kolam renang adalah jumlah angka bakteri $E$. coli sebesar < 1 colony form unit (cfu)/100 ml sampel yang diperiksa setia bulan. Dalam penelitian yang telah dilakukan oleh Joyce $d k k$ pada tahun 2017 di kota Kampa, menunjukan hasil 9 dari 13 kolam renang positif tercemar oleh bakteri $E$. coli yang diakibatkan oleh 
sistem pengelolaan kolam renang yang belum memiliki kepatuhan terkait dengan standar yang telah ditetapkan dan lemahnya penegakan hukum yang ada serta karena padatnya jumlah perenang.

Tujuan dari penelitian ini adalah untuk menganalisa kualitas air kolam renang dilihat dari keberadaan bakteri Escherichia coli dalam air kolam renang umum di wilayah kerja Puskesmas Sukodono.

\section{METODE PENELITIAN}

Penelitian ini merupakan penelitian analitik observasional dengan pendekatan cross sectional. Variabel pada penelitian ini meliputi variabel bebas (sisa klor bebas), variabel terikat (bakteri Escherichia coli) dan variabel mempengaruhi (kepadatan perenang, suhu, dan ph air kolam renang).

Populasi dalam penelitian ini adalah total kolam yang ada di 4 kolam renang umum di wilayah kerja Puskesmas Sukodono yang berjumlah 10 kolam. Sampel yang digunakan adalah air kolam renang yang ada di di wilayah keja Puskesmas Sukodono, Kabupaten Sidoarjo.
Pengambilan sampel dalam penelitian ini menggunakan teknik gabungan tempat (integrated sample. Penggunaan metode integrated sample didasari oleh kondisi karakteristik air kolam renang yang tidak banyak berubah, atau bersifat homogenitas (Fadila,2017). Pengambilan sampel air dilakukan pada 3 titik pada tiap kolam yaitu 2 sampel masing - masing di tepi kolam dan 1 sampel di tengah kolam dengan waktu pegambilan pada pagi hari (sebelum digunakan oleh pengunjung) dan sore hari (setelah digunakan oleh pengunjung).

Data yang diiperoleh kemudian akan dianalisis secara statistik dengan menggunakan uji eksak fisher untuk mengetahui jumlah perbedaan bakteri Escherichia coli pada air kolam yang mengandung sisa klor dan pada air kolam yang tidak mengandung sisa klor

\section{HASIL DAN PEMBAHASAN \\ Kepadatan Perenang}

Hasil pengukuran kepadatan perenang berdasarkan acuan Permenkes No 32 Tahun 2017 disajikan pada tabel 1.

Tabel 1.

HASIL PENGUKURAN KEPADATAN PERENANG

\begin{tabular}{|c|c|c|c|c|}
\hline No & Kepadatan & Jumlah & Prosentase & Keterangan \\
\hline 1. & $\begin{array}{l}\geq 2,2 \mathrm{~m}^{2} / \text { perenang } \\
\text { (kedalaman }<1 \mathrm{~m} \text { ) }\end{array}$ & 5 & $50 \%$ & Memenuhi Syarat \\
\hline 2. & $\begin{array}{l}\geq 2,7 \mathrm{~m}^{2} / \text { perenang } \\
\text { (kedalaman } 1- \\
1,5 \mathrm{~m} \text { ) }\end{array}$ & 3 & $30 \%$ & Memenuhi Syarat \\
\hline 3. & $\begin{array}{l}\leq 2,7 \mathrm{~m}^{2} / \text { perenang } \\
\text { (kedalaman } 1- \\
1,5 \mathrm{~m} \text { ) }\end{array}$ & 1 & $10 \%$ & Tidak Memenuhi Syarat \\
\hline \multirow[t]{2}{*}{4.} & $\begin{array}{l}\geq 4 \mathrm{~m}^{2} / \text { perenang } \\
\text { (kedalaman }>1,5 \mathrm{~m} \text { ) }\end{array}$ & 1 & $10 \%$ & Memenuhi Syarat \\
\hline & Total & 10 & $100 \%$ & \\
\hline \multicolumn{3}{|c|}{$\begin{array}{l}\text { Pada Tabel } 1 \text { terlihat bahwa } \\
\text { kepadatan perenang pada } 9 \text { dari } 10 \\
\text { kolam telah memenuhi syarat sesuai } \\
\text { dengan Permenkes No } 32 \text { Tahun } 2017 \text {. }\end{array}$} & $\begin{array}{l}\text { oleh } \\
\text { kontamir } \\
\text { muntaha } \\
\text { yang m } \\
\text { (WHO, } 2\end{array}$ & $\begin{array}{l}\text { pengunjung } \\
\text { asi non - fekal yaitu dari } \\
\text { a, air liur, atau lapisan kulit } \\
\text { encemari air kolam renang } \\
\text { 06). }\end{array}$ \\
\hline
\end{tabular}

Padat nya jumlah perenang dapat menjadi sumber kontaminasi pada air kolam, baik kontaminasi secara fekal maupun non fekal. Kontaminasi fekal berasal dari kotoran yang dikeluarkan 


\section{Suhu}

Tabel 2

HASIL PENGUKURAN SUHU AIR KOLAM RENANG

\begin{tabular}{ccccc}
\hline No & Suhu & Jumlah & Prosentase & Keterangan \\
\hline 1. & $<16^{\circ} \mathrm{C}$ & 0 & $0 \%$ & Tidak Memenuhi Syarat \\
2. & $16^{\circ} \mathrm{C}-40^{\circ} \mathrm{C}$ & 10 & $100 \%$ & Memenuhi Syarat \\
3. & $>40^{\circ} \mathrm{C}$ & 0 & $0 \%$ & Tidak Memenuhi Syarat \\
& Total & 10 & $100 \%$ & \\
\hline
\end{tabular}

Pada Tabel 2 terlihat bahwa suhu air pada 10 kolam telah memenuhi syarat. Suhu air kolam dikatakan telah memenuhi syarat apabila memiliki suhu yang berkisar antara $16^{\circ} \mathrm{C}-40^{\circ} \mathrm{C}$ (Permenkes, 2017). Jika dari hasil pengukuran, kondisi dari suhu air kolam renang, memungkinkan untuk bakteri Escherichia coli melakukan pertumbuhan. Bakteri Escherichia coli dapat tumbuh dengan suhu $20^{\circ} \mathrm{C}-$ $45^{\circ} \mathrm{C}$, sedangkan bakteri Escherichia coli akan mengalami fase dorman atau fase tidur apabila pada suhu di bawah $4^{\circ} \mathrm{C}$ dan mati pada suhu diatas $50^{\circ} \mathrm{C}$ dalam waktu 10 menit (Sunarko,2012 ;Reni 2018).

pH

Tabel 3

HASIL PENGUKURAN pH AIR KOLAM RENANG

\begin{tabular}{ccccc}
\hline No & $\mathrm{pH}$ & Jumlah & Prosentase & Keterangan \\
\hline 1. & $<7$ & 1 & $10 \%$ & Tidak Memenuhi Syarat \\
2. & $7-7,8$ & 9 & $90 \%$ & Memenuhi Syarat \\
3. & $>7,8$ & 0 & $0 \%$ & Tidak Memenuhi Syarat \\
& Total & 10 & $100 \%$ & \\
\hline
\end{tabular}

Pada Tabel 3 terlihat bahwa $\mathrm{pH}$ air pada 9 dari 10 kolam telah memenuhi syarat sesuai dengan Permenkes No 32 Tahun 2017, baik pada pengambilan air yang dilakukan pada pagi hari maupun sore hari.

Kondisi $\mathrm{pH}$ yang rendah dikarenakan masih tingginya sisa klor yang ada pada air kolam. Menjaga kondisi pH pada air kolam renang dinilai sangat penting, karena hal tersebut dijadikan sebagai kontrol klorinasi (Gordon,1976 ; Burhan, 2015). Dampak dari $\mathrm{pH}$ yang terlalu asam dan basa akan menyebabkan iritasi pada mata (McKeown,2009 ;Burhan, 2015), yang membuat ketidak nyamanan pada perenang pada saat melakukan aktivitas renang.

\section{Sisa Klor Bebas}

Sisa klor 7 dari 10 kolam renang tidak memenuhi syarat pada pengambilan yang dilakukan di pagi hari dan pada. Pengambilan sore hari terjadi peningkatan bahwa 10 kolam renang memiliki kadar sisa klor tidak memenuhi syarat sesuai dengan Permenkes No 32 Tahun 2017.

Adanya sisa klor pada air kolam renang sangat penting, karena klor bekerja sebagai desinfektan. Penggunaan desinfektan haruslah disesuaikan agar dapat memperoleh nilai sisa klor yang sesuai dengan standar yang berlaku. Penggunaan desinfektan dengan konsentrasi yang kurang dapat mengakibatkan kuman yang ada pada air kolam renang tidak terdesinfeksi secara maksimal, sedangkan apabila penggunaan desinfektan secara berlebihan dapat meninggalkan sisa klor yang dapat menimbulkan dampak bagi kesehatan (Cita dan Adriyani, 2013).

Hal - hal yang dapat menurunkan kadar klorin di air kolam renang yaitu sinar matahari, debu, kotoran, kulit, dan kontaminan dari tubuh perenang. Sehingga hal tersebut menjadi alasan bahwasannya perlu diadakannya pemantauan yang rutin pada sisa klor (Nemery dkk.,2002; Bernard dkk.,2003 ;Burhan, 2015). 


\section{Bakteri Escherichia coli}

Hasil pemeriksaan bakteri Escherihia coli yaitu 7 dari 10 kolam telah memenuhi syarat pada pengambilan di pagi hari dan 9 dari 10 kolam tidak memenuhi syarat pada pengambilan di sore hari.

Meskipun tidak semua bakteri Escherichia coli bersifat pathogen, namun beberapa studi menjelaskan bahwa konsentrasi dari bakteri Escherchia coli penyebab utama terhadap kejadian diare saat setelah melakukan aktivitas berenang (Channah dan Berenise, 2014)

Oleh karena itu meskipun air kolam renang tidak memiliki fungsi sebagai air minum bagi tiap orang, akan tetapi kualitas dari air kolam renang harus tetap terjaga dan layaknya seperti air minum. Dikatakan demikian karena perenang terkadang secara tidak sengaja meminum air kolam ketika sedang berenang, sehingga risiko tinggi kontaminasi mikroba dari air kolam akan menimbulkan dampak yang serius (Courage dan Saviour, 2015).

\section{Analisis Uji Exact fisher}

Hasil dari uji exact fisher menunjukkan bahwa nilai p-value sebesar 0,019 yang memiliki arti bahwa ada dan tidaknya kandungan sisa klor pada air kolam renang mempengaruhi keberadaan bakteri Escherichia coli dalam air kolam renang.

Faktor utama yang berpengaruh terhadap keberadaan bakteri Escherichia coli di air kolam renang adalah sisa klor bebas. Sisa klor yang ada pada air kolam digunakan sebagai desinfektan.

Penggunaan kaporit harus diperhatikan dan sesuai dengan standar. Menurut Cita dan Andriyani (2013) dampak yang ditimbulkan apabila penggunaan kaporit dalam konsentrasi yang kurang, mengakibatkan kuman yang ada di air kolam renang tidak terdesinfeksi dengan baik. Sedangkan penggunaan kaporit dengan konsentrasi yang melebihi ambang batas akan berdampak pada gangguan kesehatan seperti iritasi saluran napas, dada terasa sesak, gangguan pada tenggorokan, batuk, iritasi pada kulit dan iritasi pada mata (New York State Department Of Health,2004; Rozanto,2015)

Saat dilakukan pengukuran terhadap kadar sisa klor yang ada pada air kolam renang, dapat dibedakan menjadi 3 kriteria, yaitu kolam renang dengan kadar sisa klor yang $<1 \mathrm{mg} / \mathrm{l}$, kolam renang dengan kadar sisa klor 1$1,5 \mathrm{mg} / \mathrm{l}$ dan kolam renang dengan kadar sisa klor $>1,5 \mathrm{mg} / \mathrm{l}$.

Menurut shallichah, nurjazuli dan hanan (2016), faktor - faktor yang mempengaruhi kualitas bakteriologis air kolam renang selain sisa klor adalah tipe kolam renang, sumber asal air, $\mathrm{pH}$ dan kondisi sanitasi kolam renang.

Kolam renang yang dijadikan sebagai objek dalam penelitian ini memiliki tipe recirculating pools. Fungsi dari sistem resirkulasi adalah untuk menyaring dan membersihkan kotoran yang terdapat pada air kolam renang (Shallichah, nurjazuli dan hanan 2016). Apabila sistem resirkulasi pada air kolam renang tidak berjalan dengan baik,dampak yang ditimbulkan adalah air cepat menjadi kotor dan desinfektan akan berkurang fungsinya untuk membunuh kuman ( Department of Enviromental Health Food and Housing Division ; Shallichah ,nurjazuli dan hanan 2016).

Penelitian yang dilakukan oleh Novilla R.dkk (2014) dalam Shallichah ,nurjazuli dan hanan (2016) mengatakan bahwa penampungan sumber air dapat menjadi salah satu media kontaminasi bakteri karena tidak pernah dibuka dan tidak pernah dibersihkan oleh pengelola kolam.

WHO Guidelines For Safe Recreational Water Environments Volume 2 Swimming Pools And Similar Environment (2006) menyebutkan bahwa $\mathrm{pH}$ air kolam renang harus dikontrol guna memastikan desinfeksi dari koagulasi efisien dan menghindari kerusakan bangunan kolam renang serta menjamin kenyamanan pengguna. Selain itu menurut Resource Management Pool (2016) dalam Shallichah ,nurjazuli dan hanan (2016) nilai pH mempengaruhi kemampuan klorin dalam mengoksidasi 
materi dan membunuh mikroorganisme secara langsung.

\section{KESIMPULAN}

Hasil penelitian menyimpulkan bahwa pengukuran dari beberapa parameter fisik, kimia dan biologi menunjukkan, parameter kualitas air kolam renang yang telah sesuai dengan standar Permenkes No 32 Tahun 2017 yaitu kepadatan perenang, suhu dan $\mathrm{pH}$. Sedangkan parameter kualitas air kolam renang yang belum sesuai dengan standar Permenkes No 32 Tahun 2017 adalah sisa klor bebas dan bakteri Escherichia coli.

Selain itu terdapat hubungan antara ada dan tidaknya kadar sisa klor pada air kolam renang dengan keberadaan bakteri Escherichia coli dalam air kolam renang yang ada di wilayah kerja Puskesmas Sukodono, Kabupaten Sidoarjo.

\section{SARAN}

Adanya Eschericia coli dan kadar sisa klor yang belum memenuhi syarat, perlu mendapat perhatian pengelola kolam renang. Pengelola perlu melakukan manajemen kualitas air secara kimia dan bakteriologi agar kualitas air tetap terjaga.

\section{DAFTAR PUSTAKA}

Agustin,Reni. 2018. Kontaminasi Bakteri Escherichia Coli Pada Air Kolam Renang Di Kota Bandar Lampung. Fakultas Kedokteran Universitas Lampung.

Burhanudin I. 2015. Analisis klorin terhadap keluhan iritasi mata pada pengguna kolam renang pemerintah di Jakarta Selatan [skripsi]. Jakarta: Universitas Islam Negeri Syarif Hidayatullah.

Channah dan Berenise. 2014. Water Quality, E.coli and Your Helath .Arizona : The University of Arizona
Cita dan Andriyani. 2013. Kualitas Air Dan Keluhan Kesehatan Pengguna Kolam Renang Di Sidoarjo. Departemen Kesehatan Lingkungan Fakultas Kesehatan Masyarakat Universitas Airlangga

Courage dan Saviour. 2015. Water Quality Assessment of Swimming Pools and Risk of Spreading Infections in Ghana. Research Journal of Microbiology

Darmiah,Fadila,Imam. 2017. Hubungan Jumlah Perenang Dengan Kandungan Sisa Klor Pada Air Kolam Renang. Jurusan Kesehatan Lingkungan Poltekkes Kemenkes Banjarmasin.

Joyce dkk . 2017. Determination of Bacterial Quality of Water in Randomly Selected Swimming Pools in Kampala City, Uganda. Hindawi.

Permenkes RI No.32/MEN.KES/2017. Standar Baku Mutu Kesehatan Lingkungan dan Persyaratan Kesehatan Air Untuk Keperluan Hygiene Sanitasi, Kolam Renang, Solusi Per Aqua, Dan Pemandian Umum

Rozanto NE. 2015. Tinjauan kondisi sanitasi lingkungan kolam renang, kadar sisa khlor, dan keluhan iritasi mata pada perenang di kolam renang umum kota Semarang tahun 2015. Semarang:Universitas Negeri Semarang.

Hanan, Nur, Shallichah. 2016. Studi Kualitas Bakteriologis Air Kolam Renang Dan Faktor - Faktor Yang Mempengaruhinya Di Kolam Renang Kota Semarang.Semarang : Universitas Diponegoro

WHO.Guidelines for Safe Recretional Water Environments Volume 2 : Swimming Pools and Similar Environment. France : WHO, 2006. www.cdc.gov/healthywater/swiming/swi mmers/rwi Diakses pada tanggal 30 November 2018 pukul 12.00 WIB 